\title{
THE ANALYSIS OF CREDIT POLICY EFFECTIVENESS TO REDUCE THE LEVEL OF NON-PERFORMING LOANS: A STUDY AT PT BANK SAHABAT SAMPOERNA FOR PERIOD OF 2012-2015
}

\author{
Halomoan John Haggai Bangun*, Dwiatmanto, Endang Maria Goretti Wi \\ Faculty of Administrative Science, University of Brawijaya, Indonesia \\ *E-mail: mjohaggai@gmail.com
}

\begin{abstract}
Non-performing loans is a ratio that can describe the level of credit risk faced by banks. One of the efforts in directing bank credit is based on the healthy principles of the bank by providing a clear credit policy. The aim of this study is to analyze the credit policy on the level of non-performing loans. In this study, effective credit policy is measured through prudential banking principles, credit organization and management, credit approval policies, credit documentation and administration, credit monitoring, and settlement of non-performing loans. Meanwhile, the analysis of credit policies effectiveness is measured by bankable analysis, investment policy analysis, risk policy analysis, credit deployment policy analysis, and interest rate policy analysis. This study is descriptive research taken at PT Bank Sahabat Sampoerna in the period of 2012-2015. The data used are primary data and secondary data while the data analysis technique used in this study is descriptive analysis. The results indicate that the credit policy of PT Bank Sahabat Sampoerna has not been effective in prudential policies and bankable analysis but has been quite effective in other credit policies.
\end{abstract}

\section{KEY WORDS}

Credit, credit policy, credit policy effectiveness, non-performing loans.

To make the credit implemented consistently and based on good credit principles, each bank is required to make a written credit policy that can be used as a guideline in providing daily loans. Credit policy is very much needed because credit activities are the main activities of banks that have big risks. Therefore, in order to avoid the risks, the bank needs to be effective in lending the credit. Effectiveness (results of use) is the parameter of the organization's success in achieving the organizational goals that have been set.

Basically, effectiveness shows the level of achievement that is always associated with the understanding of efficiency even though, actually, there are differences between those two terms. Effectiveness emphasizes the results achieved while efficiency is more at how to achieve the results by comparing the input and output. The effectiveness of credit policy can be used as a reference measure to what extent the organization can achieve the objectives by using its own resources. One of the objectives to be achieved in each banking activity through credit policy is to reduce or minimize the level of Non-Performing Loans (NPLs).

The credit policy of a bank can affect the level of NPLs, that is the level of nonperforming loans ratio to the total loans issued by the banks. Therefore, credit policy plays an important role to make NPLs does not increase because a higher level of NPLs will increase the non-performing loans. Indonesian Banking Regulation number 6/10/PBI/2004 of 12 April 2004 concerning the Banking System, the Health Level of Commercial Banks states that if the value of NPLs is above $5 \%$, the bank is declared unhealthy. A good NPLs has a value below $5 \%$.

PT Bank Sahabat Sampoerna is one of the newly established banks which has had good growth. PT Bank Sahabat Sampoerna attempts to make a breakthrough so that the system of lending to debtors could be more efficient and effective in an effort to make the level of NPLs decreased every year. The efforts to reduce the NPLs level of the banks are implemented through effective and consistent credit policies.

Non-performing loans (NPLs) cannot be avoided, but banks must be able to reduce or minimize it so that it will not exceed the level of credit health standards. Since the increase in 
credit can increase NPLs, PT Bank Sahabat Sampoerna must always be selective in assessing the creditworthiness proposed by prospective customers. The role of credit policy is essential in the provision of credit so that banks can prevent the losses due to the distributed credit that are not returned so as to minimize the potential risks.

\section{LITERATURE REVIEW}

In the Indonesian term, commercial bank is also known as bank umum. Commercial banks basically carry out business activities in a conventional manner or based on sharia principles whose activities provide services in payment traffic. In Law number 23 of 1999 and as amended by Law number 3 of 2004 concerning banking, a bank is defined as a business entity that collects funds from the public in the form of deposits or savings which then distributes them to the public in the form of loans or other means in order to increase the welfare of the public itself.

Effectiveness is the use of certain amounts of resources, facilities, and infrastructure that are consciously set beforehand to produce a number of goods for the services and activities carried out (Sondang, 2008). In line with that, Abdurahmat (2008) revealed that effectiveness is the utilization of resources, facilities, and infrastructure in a certain amount that is consciously set beforehand to produce a number of jobs on time.

The Law of Banking number 10 of 1998 concerning credit defines credit as "the provision of money or claims that are equivalent based on the agreement between banks and other parties that requires the debtors to repay the debt plus interest after a certain period of time".

Credit is given based on trust so that credit is actually a gift of trust. This means that creditors believe that the debtors will return the credit according to the specified period of time and agreement. Based on that explanation, Kasmir (2013) said that the elements of credit are trust, agreement, and remuneration.

Before lending the credit, the bank has to be sure that the debtors can be trusted so that the bank must do an assessment or analysis before the credit is distributed. The assessment criteria that must be carried out by the bank to get debtors is based on the $5 \mathrm{C}$ principles (Character, Capacity, Capital, Condition of Economy, and Collateral) (Ariyanti, 2009).

According to Ali (2004), non-performing loans (NPLs) reflects credit risks. The higher the NPLs level, the bigger the credit risks faced by banks. On the other hand, Almalia (2005: 137) wrote that NPLs ratio shows the ability of the bank in managing the bad credit. Based on the provisions from Bank Indonesia in the Circular Letter of Bank Indonesia number 12/11/DPNP of 2010, the ratio of non-performing loans can be formulated as follows:

Non-Performing Loan (NPLs) = Total Bad Credit x 100\%

Based on the research of Hasibuan (2005), a policy is comprehensive guidelines in oral and written form that provides general boundary and direction where management action will take place. Meanwhile, Puspopranoto (2004) said that credit activities of a bank require general guidelines or credit policies to help the officers involved in the process of making credit decisions.

\section{METHODS OF RESEARCH}

This study is descriptive research because it will describe or display a number of objects that are examined systematically, properly, and accurately. This research was conducted at PT Bank Sahabat Sampoerna, Jalan Jend. Sudirman Kav. 45 Jakarta. The data sources used in this study are primary data and secondary data. Whereas, the data collection techniques were done through interview and documentation. Based on the data 
collection techniques, the research instruments used were the researchers themselves, interview guidelines, and documentation. The data analysis method used in this study is a descriptive analysis that describes the level of non-performing loans (NPLs) of the bank by looking at the financial condition and effectiveness of credit management applied by PT Bank Sahabat Sampoerna. The data analysis step that will be carried out by researchers to determine the effectiveness of credit management to the level of NPLs is:

The effective credit policy at PT Bank Sahabat Sampoerna. Analyzing the effectiveness of credit policy at PT Bank Sahabat Sampoerna. Calculating and analyzing the bad credit and the percentage of Non-Performing Loans (NPLs) in the period of 2012 to 2015 at PT Bank Sahabat Sampoerna.

\section{RESULT OF STUDY}

The prudential banking principles should be properly applied by PT Bank Sahabat Sampoerna. However, several factors related to credit agreements such as installment payments often become a constraint in a bank and as a result, affect the level of NPLs ratio.

In regard to that, these are the things applied by PT Bank Sahabat Sampoerna that are in concern with prudential banking principles:

- Determine the maximum limit of the loans;

- Specify the plafond of each credit;

- Set the procedure of credit issuance.

In fact, PT Bank Sahabat Sampoerna also has difficulties in maintaining the prudential banking principles, including:

- Not separating officials or departments that handle good credit, bad credit, and nonperforming loans;

- Credit monitoring is not strict because there are lots of bad credits.

Table 1 - Collectability Data for the Period of 2012-2015 at PT Bank Sahabat Sampoerna

\begin{tabular}{|c|c|c|c|c|}
\hline Year & 2012 & 2013 & 2014 & 2015 \\
\hline Distributed Credit & $1,065,981,000,000$ & $1,731,636,000,000$ & $2,539,905,000,000$ & $4,730,028,000,000$ \\
\hline Performing & $1,038,052,297,800$ & $1,704,102,987,600$ & $2,480,217,232,500$ & $4,591,438,179,600$ \\
\hline $\begin{array}{c}\text { Non-performing } \\
\text { Loans: }\end{array}$ & & & & \\
$\begin{array}{c}\text { a. Less Performing } \\
\text { b. Doubtful } \\
\text { c. Default }\end{array}$ & $24,023,000,000$ & $25,124,000,000$ & $52,457,000,000$ & $120,140,000,000$ \\
\hline $\begin{array}{c}\text { Alternatives / } \\
\text { Reserve Money }\end{array}$ & $15,905,702,200$ & $2,114,012,400$ & $\begin{array}{c}6,210,000,000 \\
1,020,500\end{array}$ & $\begin{array}{c}15,992,000,000 \\
2,457,000\end{array}$ \\
\hline
\end{tabular}

Source: PT Bank Sahabat Sampoerna, 2016.

Based on the data above, it can be seen that the number of NPLs has increased from 2012 to 2015.

The credit organization and management of PT Bank Sahabat Sampoerna has been effective and implemented according to the responsibilities of each division. In each work unit, there is a division of authority that each of them plays an important role in making credit decisions. The divisions involved in credit organization and management are the Board of Directors, Head of Operational Division, General Affairs Division, and Credit Division consisting of relation officer, marketing, and administration staff. Each division has carried out its management duties properly and in accordance with the procedures at PT Bank Sahabat Sampoerna.

The policy of credit approval is carried out well in accordance with the procedures applied by the bank. The credit approval policy at PT Bank Sahabat Sampoerna has several components including the concept of total credit relationship, setting of authority limits, 
responsibilities of credit breaker officials, credit approval process, credit agreements, and approval of credit disbursement. There are stages that need to be evaluated and updated even though these components have been run properly. At the stage of credit breaker responsibility, it is expected that the bank can be more comprehensive in understanding the character of a person; it is expected that the bank can know the secondary and primary needs and lifestyle of the applicants so that the credit analysts can fully understand their character.

Credit documentation and administration at PT Bank Sahabat Sampoerna is already good. The documents that become the bank's requirements have been carried out in an orderly and neat manner. Documents administration is intended to support credit monitoring and the assessment of credit development or customer business so that the interests of the bank can be protected.

PT Bank Sahabat Sampoerna already has good credit monitoring on its customers. This is based on the smooth installment payments. The bank also monitors the customer's sustainability in fulfilling his/her responsibilities.

The settlement of non-performing loans made by PT Bank Sahabat Sampoerna is already good by setting 4 credit settlement categories namely collect 1 , collect 2 , collect 3 , and collect 4 . This has been very effective because the bank resolves and monitors the payment of customers directly. The bank also uses a method of settlement in the form of rescheduling, reconditioning, restructuring, combining, and foreclosure very precisely on the customer's condition.

Based on the data obtained, it is shown that the credit provided by PT Bank Sahabat Sampoerna does not meet the safety and effectiveness criteria as indicated by the assessment based on the credit repayment for credit customers. The credit repayment assessment illustrates safety covers the accuracy of principal and interest payment on the availability and accuracy of debtor financial information. Whereas, on the other hand, the credit repayment assessment that describes effectiveness includes the assessment of documents completion when applying for funds and the rational source of payment.

Besides that, the results clarify that PT Bank Sahabat Sampoerna has established an investment policy, both primary investments and secondary investments. Primary investments are used to meet the needs of bank facilities and infrastructure while secondary investments are made to channel the loans to debtors.

PT Bank Sahabat Sampoerna has made healthy loans distribution through the process of receiving credit applications, credit analysis, and credit realization. This has been done by credit analysts in accordance with the $5 \mathrm{C}$ principles in carrying out the credit assessment standards of PT Bank Sahabat Sampoerna which have been written in the credit implementation guidelines, namely character, capacity, capital, collateral, and condition of the economy. Table 2 below points out the $5 \mathrm{C}$ principles and standards at PT Bank Sahabat Sampoerna.

Table 2 - 5C Principles and Standards at PT Bank Sahabat Sampoerna

\begin{tabular}{|l|l|l|}
\hline No5C Principles & Standards at PT Bank Sahabat Sampoerna \\
\hline 1. & Character & $\begin{array}{l}\text { Seen from the credit applications made by prospective debtors and from the results of } \\
\text { interviews between the marketing department and prospective debtors. BI Checking. }\end{array}$ \\
\hline 2. & Capacity & $\begin{array}{l}\text { Viewed from the income of prospective debtors minus the cost of living per month. Usually, it } \\
\text { is } 70 \% \text { of the net income. Moreover, this is seen from the business that is run by prospective } \\
\text { debtors; whether or not the business has a good prospect. }\end{array}$ \\
\hline 3. & Capital & $\begin{array}{l}\text { Observed from the professionalism of prospective debtors in carrying out their business; } \\
\text { how long does the business run, how many businesses that the debtors have, and how is } \\
\text { the current business condition. This is also assessed from financial reports and checking } \\
\text { accounts to see business turnover. }\end{array}$ \\
\hline 4. & Collateral & Based on land and building certificates. \\
\hline 5. & $\begin{array}{l}\text { Condition } \\
\text { Economy }\end{array}$ & of Interest rates of Bank Indonesia. Inflation rate. \\
\hline
\end{tabular}

The determination of risk policies carried out by PT Bank Sahabat Sampoerna can reduce credit risks if it is performed properly and correct. In addition, the $5 \mathrm{C}$ analysis will 
provide confidence to the bank regarding the ability of its debts in a disciplined manner, both the principal and interest payments in accordance with the agreement between banks and debtors. However, to improve credit rating, it is recommended that PT Bank Sahabat Sampoerna add another factor to its credit analysis that is Constraint. A constraint is a limitation and obstacle that does not allow a business to be carried out in a certain place. As for example, the establishment of a gas station business that is adjacent to coal burning will endanger the business activity.

In terms of credit distribution, PT Bank Sahabat Sampoerna has set its own policies, namely Working Capital Credit (Kredit Modal Kerja or KMK) for Multifinance, Employee Cooperatives (Koperasi Karyawan), Rural Banks (Bank Perkreditan Rakyat or BPR), as well as Consumer Loans for individuals (Kredit Konsumsi). The most productive credit amongst those credit types is Working Capital Credit because the economy level has increased dramatically.

Table 3 - The Level of Non-Performing Loans (NPLs) at PT Bank Sahabat Sampoerna, 2012- 2015 Period

\begin{tabular}{|c|c|c|c|c|}
\hline Year & Total Bad Credit & Distributed Working Capital Credit & NPLs (gross) & Category \\
\hline 2012 & $27,928,702,200$ & $1,065,981,000,000$ & $2.62 \%$ & Good \\
\hline 2013 & $27,533,012,400$ & $1,731,636,000,000$ & $1.59 \%$ & Excellent \\
\hline 2014 & $59,687,767,500$ & $2,539,905,000,000$ & $2.35 \%$ & Good \\
\hline 2015 & $138,589,820,400$ & $4,730,028,000,000$ & $2.93 \%$ & Good \\
\hline
\end{tabular}

Source: Processed Data, 2016.

Based on the Table 3 above, it can be seen that the increase in the number of bad credit is followed by an increase in the percentage of NPLs and vice versa, if the number of bad credit decreases, the percentage of NPLs will also decrease. It is known that the percentage of NPLs from 2012 to 2015 is still far from the maximum percentage of NPLs set by Bank Indonesia at 5\%.

\section{CONCLUSION}

The level of Non-Performing Loans (NPLs) found in PT Bank Sahabat Sampoerna is in a good indicator (healthy). However, the bank's performance in managing the bad credit needs to be reviewed and re-evaluated.

\section{SUGGESTIONS}

It is expected that the management of PT Bank Sahabat Sampoerna will further enhance the research on prudential banking principles in assessing prospective customers. This is related to the high level of NPLs and also to pay attention to the quality of credit given so as not to become bad credit thus the bank can benefit from the loans distributed.

The monitoring of debtors needs to be carried out routinely in order to discover early problems that might occur. The bank needs to hold regular visits to debtors in an effort to anticipate the case of Non-Performing Loans.

\section{REFERENCES}

1. Abdurahmat, F. (2008). Organisasi dan Manajemen Sumber Daya Manusia. Bandung: Remaja Rosda Karya.

2. Ali, M. (2004). Asset Liability Management: Menyiasati Risiko Pasar dan Risiko Operasional. Jakarta: Gramedia.

3. Almalia. (2005). Analisis Rasio CAMEL Terhadap Prediksi Kondisi Bermasalah Pada Lembaga Perbankan (Unpublised Thesis). Universitas Airlangga, Surabaya.

4. Arthesa, A., \& Edia, H. (2006). Bank dan Lembaga Keuangan Bukan Bank. Jakarta: Indeks Kelompok Gramedia. 
5. Bank Indonesia. (2010). Surat Edaran Bank Indonesia No. 6/23/DPNP. Retrieved from www.bi.go.id.

6. Bank Indonesia. (2010). Surat Edaran Bank Indonesia No. 12/11/DPNP. Retrieved from www.bi.go.id.

7. Hasibuan, H. M. (2005). Dasar-Dasar Perbankan. Jakarta: PT. Bumi Aksara.

8. Kasmir. (2012). Manajemen Perbankan. Jakarta: PT Raja Grafindo Persada.

9. Puspopranoto, S. (2004). Keuangan Perbankan dan Pasar Keuangan: Konsep, Teori, dan Realita. Jakarta: Penerbit Pustaka LP3ES Indonesia.

10. Siamat, D. (2004). Manajemen Lembaga Keuangan. Jakarta: Lembaga Penerbit Fakultas Ekonomi Universitas Indonesia.

11. Triandaru, S. (2006). Bank dan Lembaga Keuangan Lainnya. Jakarta: Salmeba Empat.

12. Undang-undang Republik Indonesia Nomor 10 tahun 1998 Tentang Perubahan UndangUndang Nomor 7 Tahun 1992 Tentang Perbankan. 